\title{
Double blind controlled study of low dose intravenous perindoprilat or enalaprilat infusion in elderly patients with heart failure
}

\author{
R J MacFadyen, K R Lees, J L Reid
}

\begin{abstract}
Objective-Comparison of the first dose responses to low dose constant rate infusions of diacid angiotensin converting enzyme (ACE) inhibitors.

Design-Double blind, randomised, placebo controlled, parallel group prospective study.

Setting-General hospital inpatient admissions for supervised diuretic withdrawal (24-48 hours) and the introduction of ACE inhibitor treatment.

Patients-36 unselected elderly (aged 60-87 years) patients with symptomatic but stable chronic cardiac failure (New York Heart Association grades II-IV). ACE inhibitor started under double blind conditions with blood pressure monitoring.
\end{abstract}

Intervention-Patients were randomly allocated to receive intravenous placebo (saline), enalaprilat (1.5 mg over six hours) or perindoprilat (1 $\mathrm{mg}$ over six hours) by constant rate intravenous infusion ( $5 \mathrm{ml} / \mathrm{hour}$ ). The protocol allowed for discontinuation of infusion if mean arterial blood pressure fell by $30 \%$ from the value before treatment.

Main outcome measures-Blood pressure and heart rate responses, drug concentration, plasma renin, and ACE activities.

Results-The three groups had similar age, severity of heart failure, diuretic dose before treatment, plasma renin activity, and serum electrolyte state. All patients remained symptom free throughout the study. Infusions were only ended early with active treatment: 5/12 perindoprilat cases, (mean (SD) dose $0.88(0.18) \mathrm{mg}$, and $5 / 12$ enalaprilat cases (mean (SD) dose $1.2(0.4)$ mg. Both active treatments lowered mean arterial pressure until discontinuation of infusion. Heart rate was not altered. Two patients (one perindoprilat, one enalaprilat) showed transient and symptom free renal impairment.

Conclusions-Slow intravenous infusion of diacid ACE inhibitors may allow safe initiation of treatment in patients with heart failure and with activated renin angiotensin systems. The similar effects of intravenous perindoprilat and enalaprilat on blood pressure contrast with previously reported differences when perindopril and enalapril were given orally.

\section{(Br Heart f 1993;69:293-297)}

Angiotensin converting enzyme (ACE) inhibitors are now routinely used in the medical management of chronic cardiac failure. They relieve symptoms, ${ }^{1}$ reduce long-term mortality, ${ }^{2}$ and their beneficial effects are probably evident regardless of the aetiology of heart failure or the severity of the disease. ${ }^{3}$ The mechanism of action of these drugs in heart failure seems complex. Various effects on haemodynamics, central and regional perfusion pressures, vascular and cardiac structure, neurohormonal responses, and electrolyte handling may all play a part in the symptomatic response and in reducing mortality. ${ }^{4}$

Although ACE inhibitors are not strictly specific, affecting other systems including kinins and prostaglandins, and having important interactions with autonomic tone and baroreflexes, these drugs probably act primarily by blocking angiotensin generation in plasma and tissues. ${ }^{5}$ The relative importance of blockade of the generation of circulating or tissue based angiotensin in heart failure is unclear. ${ }^{6}$

Experimental evidence suggests that the structural changes of hypertension and heart failure such as ventricular hypertrophy or dilatation can be reversed, without a significant lowering effect on blood pressure by very low doses of ACE inhibitors. ${ }^{7}$ The role of haemodynamic changes in mediating the symptomatic response or improved survival in chronic cardiac failure is unknown.

During initiation of treatment, variable and occasionally profound falls in blood pressure have been found. ${ }^{8}$ Prediction of these responses in individual patients has not always been possible, although activation of the renin angiotensin system is usually implicated.

Angiotensin converting enzyme inhibitors prevent or reduce and reverse ventricular dilatation after myocardial infarction..$^{910}$ In the peri-infarction period substantial hypotensive responses may be undesirable. It has been proposed that intravenous initiation of treatment might minimise any change in blood pressure. ${ }^{1011}$

We have compared the intravenous diacid ACE inhibitors perindoprilat and enalaprilat 
with placebo in patients with chronic cardiac failure by a hospital protocol of short term diuretic withdrawal. We were interested to compare the responses to different ACE inhibitor drugs and to examine the usefulness of a prolonged $(6 \mathrm{~h})$ infusion.

\section{Patients and methods}

DESIGN AND PATIENTS

This study was conducted in 36 elderly patients (aged 60-87 years; 24 men) admitted to hospital for initiation of ACE inhibitors as additional treatment for the management of chronic cardiac failure. Patients were all symptomatic on diuretic treatment ( $\geqslant 80 \mathrm{mg}$ frusemide or equivalent daily) and none had significant fluid imbalance. All patients had stable renal function and normal serum sodium state $(\mathrm{Na} \geqslant 135 \mathrm{mmol})$ before treatment. The diagnosis of chronic cardiac failure was confirmed by enquiry about symptoms, clinical history, and physical, radiological, and electrocardiographic examination before treatment. All patients had New York Heart Association (NYHA) symptoms grades IIIV; most were grade III, symptomatic on minimal exertion. Table 1 shows the clinical details of the three patient groups.

This study was part of a larger double blind parallel group study of both intravenous ACE inhibitors and oral dosing with captopril, perindopril, and enalapril. Separate analysis of the two parts was specified in the original study protocol. The results of the study of oral dosing have already been reported. ${ }^{12}$

\section{PROCEDURE}

All diuretic treatment was withdrawn under supervision for at least 24 hours and usually 48 hours before ACE inhibitor treatment. Concomitant vasoactive drugs such as calcium antagonists or nitrate preparations were withheld on the day of treatment and until after monitoring was completed at 24 hours. Digoxin, where prescribed, was continued unaltered. On the morning of treatment (about 07.30) two heparinised peripheral venous cannulae were inserted for blood sampling and infusion purposes in contralateral

Table 1 Summary of demographic and laboratory variables and absolute starting blood pressures (mean (SD)) with statistical comparisons between groups

\begin{tabular}{|c|c|c|c|c|}
\hline & Placebo & Enalaprilat & Perindoprilat & $\begin{array}{l}\text { P value } \\
(\text { ANOVA })\end{array}$ \\
\hline Age $(y r)$ & $68(6)$ & $70(6)$ & $69(6)$ & 0.822 \\
\hline Plasma renin activity $\left(\mathrm{nmol} \cdot \mathrm{h}^{-1} \cdot \mathrm{ml}^{-1}\right.$ ) & 3.9 & $2 \cdot 3$ & $2 \cdot 2$ & 0.681 \\
\hline Frusemide dose (mg) & $110(61)$ & $100(41)$ & $83(30)$ & 0.493 \\
\hline NYHA class II & 3 & 2 & 5 & 0.390 \\
\hline NYHA class III & & 10 & & \\
\hline Serum $\mathrm{Na}^{+}\left(\right.$mmol. $\left.1^{-1}\right)$ & $139(2)$ & $141(2)$ & $140(4)$ & $0 \cdot 582$ \\
\hline Serum $\mathrm{K}^{+}\left(\mathrm{mmol} .1^{-1}\right)$ & $4 \cdot 1(0 \cdot 6)$ & $4.0(0.4)$ & $4 \cdot 3(0.4)$ & 0.363 \\
\hline Serum Urea $\left(\mathrm{mmol} . \mathrm{1}^{-1}\right)$ & $8.5(5.6)$ & $8 \cdot 2(2 \cdot 8)$ & $8 \cdot 0(3 \cdot 3)$ & 0.958 \\
\hline $\begin{array}{l}\text { Serum Creatinine } \\
\left(\mu \text { mol. } 1^{-1}\right)\end{array}$ & $107(14)$ & $108(27)$ & $101(24)$ & $0 \cdot 836$ \\
\hline $\begin{array}{l}\text { Supine heart rate } \\
\text { (beats } / \mathrm{min} \text { ) }\end{array}$ & $81(13)$ & $74 \cdot 3(8)$ & $78 \cdot 5(14)$ & $0 \cdot 724$ \\
\hline $\begin{array}{l}\text { Systolic blood } \\
\text { pressure }(\mathrm{mm} \mathrm{Hg})\end{array}$ & $139 \cdot 6(18)$ & $134 \cdot 5(30)$ & $128 \cdot 4(14)$ & 0.703 \\
\hline $\begin{array}{l}\text { Diastolic blood } \\
\text { pressure }(\mathrm{mm} \mathrm{Hg})\end{array}$ & $80 \cdot 6(13)$ & $76.9(11)$ & $72 \cdot 1(11)$ & $0 \cdot 821$ \\
\hline $\begin{array}{l}\text { Mean arterial } \\
\text { pressure }(\mathrm{mm} \mathrm{Hg})\end{array}$ & $100 \cdot 3(13)$ & $99 \cdot 1(14)$ & $89 \cdot 1(10)$ & 0.690 \\
\hline
\end{tabular}

antecubital fossae. The patient then rested undisturbed, supine in bed, while baseline blood pressure was recorded semiautomatically at two minute intervals for at least 30-60 minutes (Sentron, Bard, Sunderland, United Kingdom). Infusions (saline placebo, $1.5 \mathrm{mg}$ of enalaprilat, $1 \mathrm{mg}$ of perindoprilat) were given double blind in accordance with a randomisation schedule held by the Department of Pharmacy. All patients received their normal meals throughout the study. They were kept supine until 10 hours after the start of infusion. The protocol stipulated the end of infusion without withdrawal from the study on the basis of a fall of $30 \%$ from the baseline mean arterial pressure established over 30-60 minutes before start of infusion. This was intended to test if the end of infusion would control the drug induced fall in blood pressure. Patients were kept supine for at least 45 minutes before sampling and blood pressure measurement at 24 hours. After the start of the infusion blood pressure was recorded supine at two minute intervals and with blood samples drawn for triplicate determination of drug concentration and ACE activity at 0 , $0.08,0.16,0.25,0.33,0.5,0.67,0.83,1$, $1 \cdot 25,1 \cdot 5,1 \cdot 75,2,2 \cdot 5,3,3 \cdot 5,4,4 \cdot 5,5,5 \cdot 5$, $6,6 \cdot 5,7,8,9,10$ and 24 hours. At $0,2,4,6$, 8,10 and 24 hours blood samples were drawn for determination of plasma renin activity.

At 24 hours after dosing, blood pressure, drug concentrations, hormones, routine biochemistry, and haematology were determined after a period of supine rest (45 minutes). The treatment code was then broken to allow appropriate further management. Patients on enalaprilat continued on active treatment with enalapril $5 \mathrm{mg}$ twice daily and their other diuretics and vasodilators were reinstated. Patients who had received placebo continued without diuretics and received $6.25 \mathrm{mg}$ of oral captopril as open treatment under normal nursing observation in hospital. These patients were not subsequently included in any other study group.

The study was approved by the local research and ethics committee and all patients gave informed and written consent to o observation at the start of their new treatment.

\section{LABORATORY AND STATISTICAL ANALYSES}

Drug concentrations and plasma ACE activity were determined by the measurement by high pressure liquid chromatography of the production of hippuric acid upon incubation with the substrate hippuryl-histidylleucine. ${ }^{1314}$ Total plasma renin activity was estimated by radioimmunoassay of angiotensin I, formed after the addition of exogenous angiotensinogen. ${ }^{15}$

Blood pressure and heart rate were recorded in triplicate and mean recordings were used for the statistical analysis. Mean arterial pressure was calculated as diastolic pressure plus one third of the pulse pressure.

The absolute values of heart rate and mean arterial pressure before treatment were sub- 
Table 2 Individual maximal fall in mean arterial pressure with time recorded and duration of infusion in each of the three treatment groups

\begin{tabular}{|c|c|c|c|c|c|c|c|c|c|}
\hline \multirow[b]{2}{*}{ Case } & \multicolumn{3}{|l|}{ Placebo } & \multicolumn{3}{|l|}{ Enalaprilat } & \multicolumn{3}{|c|}{ Perindoprilat } \\
\hline & $\begin{array}{l}\text { Mean } \\
\text { arterial } \\
\text { pressure } \\
(\mathrm{mm} \mathrm{Hg})\end{array}$ & $\begin{array}{l}\text { Time } \\
\text { (h) }\end{array}$ & $\begin{array}{l}\text { Infusion } \\
\text { (h) }\end{array}$ & $\begin{array}{l}\text { Mean } \\
\text { arterial } \\
\text { pressure } \\
(\mathrm{mm} \mathrm{Hg})\end{array}$ & $\begin{array}{l}\text { Time } \\
\text { (h) }\end{array}$ & $\begin{array}{l}\text { Infusion } \\
\text { (h) }\end{array}$ & $\begin{array}{l}\text { Mean } \\
\text { arterial } \\
\text { pressure } \\
(\mathrm{mm} \mathrm{Hg})\end{array}$ & $\begin{array}{l}\text { Time } \\
\text { (h) }\end{array}$ & $\begin{array}{l}\text { Infusion } \\
\text { (h) }\end{array}$ \\
\hline $\begin{array}{l}1 \\
2 \\
3 \\
4 \\
5 \\
6 \\
7 \\
8 \\
9 \\
10 \\
11 \\
12 \\
\end{array}$ & $\begin{array}{r}-4 \\
-16 \\
-8 \\
-27 \\
-17 \\
-8 \\
-10 \\
-16 \\
-12 \\
-32 \\
-10 \\
-24 \\
\end{array}$ & $\begin{array}{l}0.33 \\
4 \cdot 5 \\
6 \\
5 \cdot 5 \\
4 \\
0.33 \\
2 \\
4 \\
4 \cdot 5 \\
5 \\
7 \cdot 5 \\
0.08\end{array}$ & $\begin{array}{l}6 \\
6 \\
6 \\
6 \\
6 \\
6 \\
6 \\
6 \\
6 \\
6 \\
6 \\
6 \\
\end{array}$ & $\begin{array}{l}-15 \\
-23 \\
-15 \\
-19 \\
-21 \\
-19 \\
-33 \\
-38 \\
-30 \\
-45 \\
-25 \\
-40 \\
\end{array}$ & $\begin{array}{l}0.67 \\
3.5 \\
5 \cdot 5 \\
4.5 \\
2 \\
2.5 \\
6 \\
2.5 \\
3.5 \\
5 \\
4 \cdot 5 \\
4.5 \\
\end{array}$ & $\begin{array}{l}6 \\
6 \\
6 \\
6 \\
2 \\
2 \\
6 \\
6 \\
3 \\
4 \\
6 \\
5\end{array}$ & $\begin{array}{r}-9 \\
-29 \\
-30 \\
-29 \\
-47 \\
-18 \\
-11 \\
-25 \\
-29 \\
-23 \\
-15 \\
-27 \\
\end{array}$ & $\begin{array}{l}4 \\
2 \cdot 5 \\
5 \\
4 \cdot 5 \\
4 \cdot 5 \\
2 \cdot 5 \\
4 \cdot 5 \\
4 \\
4 \cdot 5 \\
4 \cdot 5 \\
4 \cdot 5 \\
6 \\
\end{array}$ & $\begin{array}{l}6 \\
2 \cdot 5 \\
5 \\
6 \\
2 \cdot 5 \\
6 \\
6 \\
6 \\
5 \\
4 \\
6 \\
6 \\
\end{array}$ \\
\hline
\end{tabular}

jected to repeated measures analyses of variance with the statistical package RUMMAGE on an ICL 3988 mainframe computer. The data after treatment were corrected to the baseline before analysis. The variance model included two fixed factors (time, with $28 \mathrm{lev}$ els, and treatment, with three levels) and one random factor (patients, with 12 levels). Individual treatment comparisons at each time were estimated by Bonferroni correction; individual times within each treatment were not compared.

Inhibition of ACE was calculated from the formula:

$\%$ inhibition $=100 \times(1-\mathrm{ACE}$ after treatment/ACE before treatment)

Plasma renin activity was assessed after logarithmic transformation.

The demographic data, baseline sodium creatinine, and renin values, and treatment effects on laboratory indices were compared among the treatment groups with a one way analysis of variance. The NYHA classification of heart failure severity was assessed by Kruskal-Wallis analysis of variance by ranks.

\section{Results}

GENERAL

The three treatment groups had comparable age, NYHA grading, diuretic dosage, plasma renin activity, and serum electrolytes before treatment (table 1). Laboratory indices were

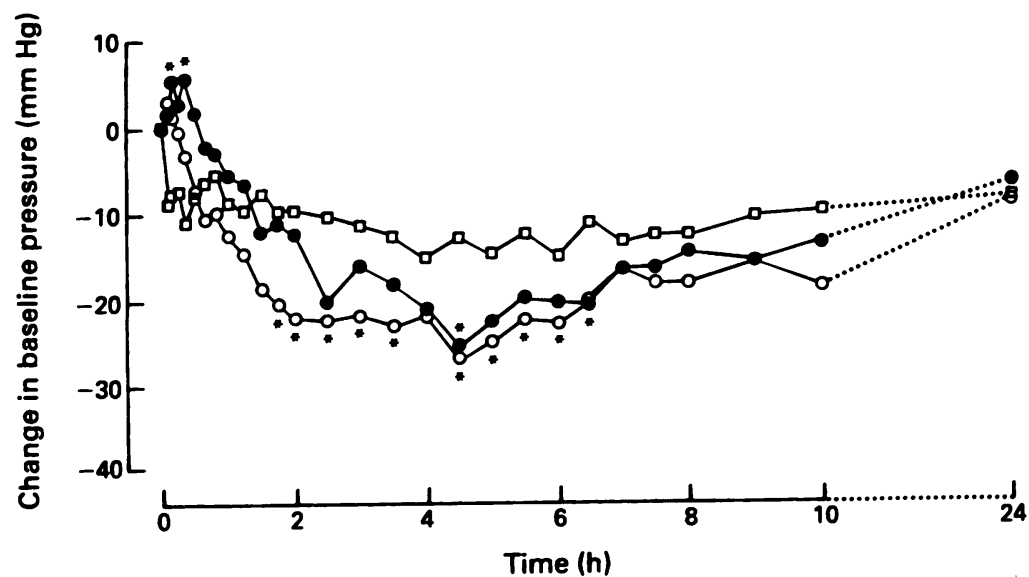

Figure 1 Baseline corrected change in systolic blood pressure (mean values, $n=12$ ) after intravenous placebo ( $\square$ ), enalaprilat (O), or perindoprilat (O) in elderly patients with chronic heart failure $\left(^{\star} p<0.05 v\right.$ placebo). not significantly influenced by treatment. The small fall in haemoglobin concentration found in all three groups (placebo, -1.3 $(0.5)$; enalaprilat, $-1.2(0.7)$; perindoprilat, $-1.3(0.8) \mathrm{g} / \mathrm{dl})$ was similar $(\mathrm{p}=0.930)$ and was attributed to the sampling of about 350 $\mathrm{ml}$ blood over 24 hours.

All patients tolerated treatment without symptoms. Two patients on active treatment (one, perindoprilat; one, enalaprilat) showed symptom free transient increases in serum urea and creatinine concentrations at 24 hours after treatment. Maintenance treatment with oral enalapril (5 mg twice daily) was subsequently discontinued in these patients and renal function returned to normal.

\section{HAEMODYNAMIC RESPONSES}

Table 1 shows the group mean absolute blood pressure and heart rate values before treatment. These were not significantly different from each other. There were no significant differences in heart rate between the active groups and placebo during the observation period.

No placebo infusion was terminated. During the early phases of infusion both active treatments showed a transient rise in systolic blood pressure, but not in mean arterial pressure. In each of the active treatment groups five infusions were ended early in the enalaprilat group at $2,2,3,4$, and 5 hours; and in the perindoprilat group at $2.5,2.5,4$, 5 , and 5 hours. The mean total dose of enalaprilat was therefore $1.2(0.4) \mathrm{mg}$ and of perindoprilat $0.88(0.18) \mathrm{mg}$. The mean responses shown beyond two hours therefore do not reflect continuing infusion in all cases (fig 1).

Table 2 shows the relation between individual maximal recorded fall in MAP, the corresponding time, and the duration of infusion for all three treatment groups. The maximal mean fall in MAP (greatest fall in group data) was $-10.4 \mathrm{~mm} \mathrm{Hg}$ at six hours during placebo infusion, $-22.3 \mathrm{~mm} \mathrm{Hg}$ at five hours during enalaprilat infusion and $-18.6 \mathrm{~mm}$ $\mathrm{Hg}$ at 4.5 hours during perindoprilat infusion. The means of the patients' maximum falls in blood pressure were $-34.9(12.3)$ for perindoprilat, $-38.8(11.3)$ for enalaprilat, and $-16.4(7 \cdot 7)$ for placebo. Early end of 

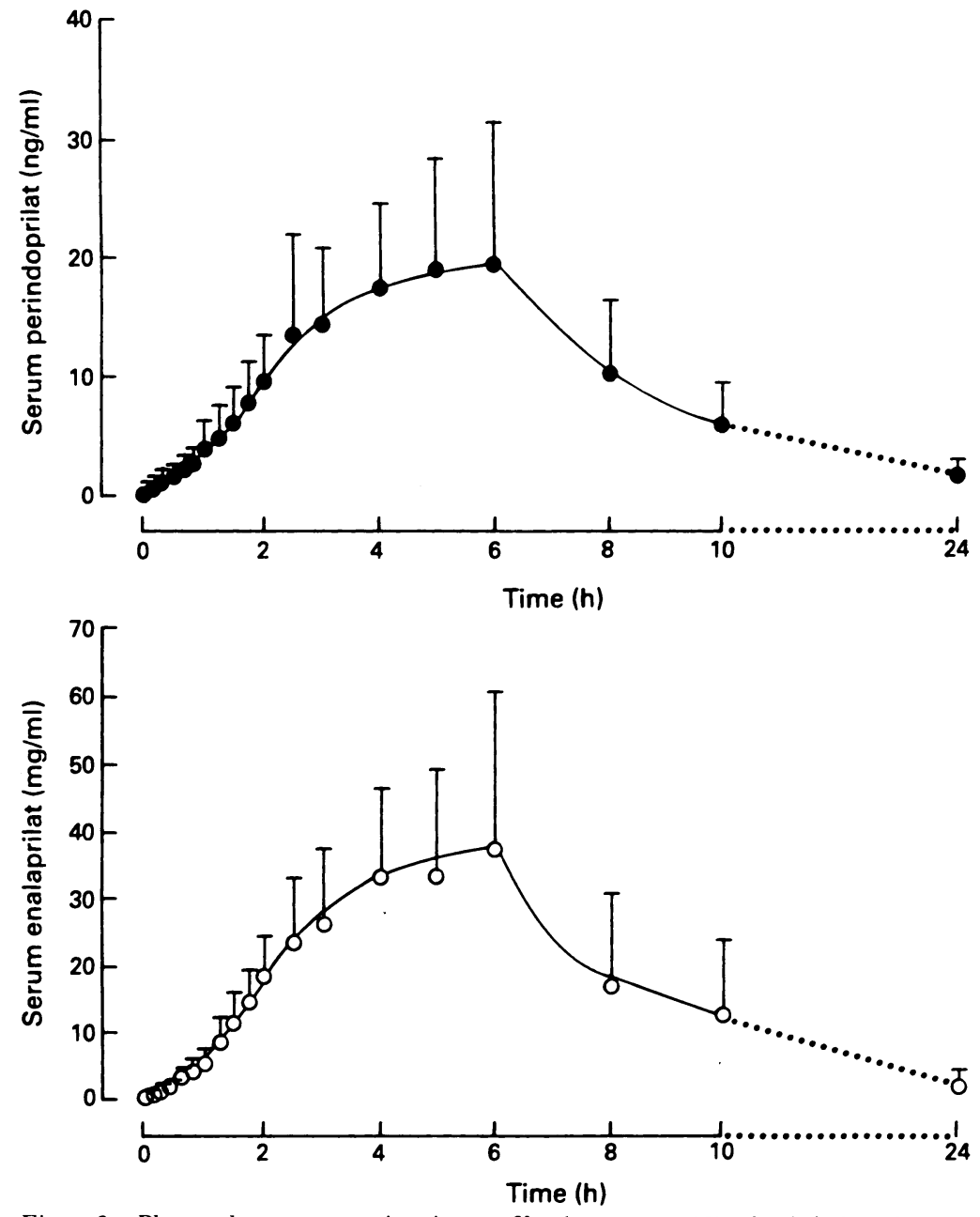

Figure 2 Plasma drug concentration time profiles (mean, $n=12$ ) after infusion of perindoprilat (O) or enalaprilat $(\bigcirc)$.

infusion successfully controlled the fall in blood pressure. The minimum MAP always followed the end of treatment by 15-30 minutes.

DRUG CONCENTRATION AND PLASMA HORMONAL RESPONSES

Figure 2 shows the pharmacokinetic profiles for the enalaprilat and perindoprilat groups. They include the data from the infusions that were ended early. The mean time to peak for

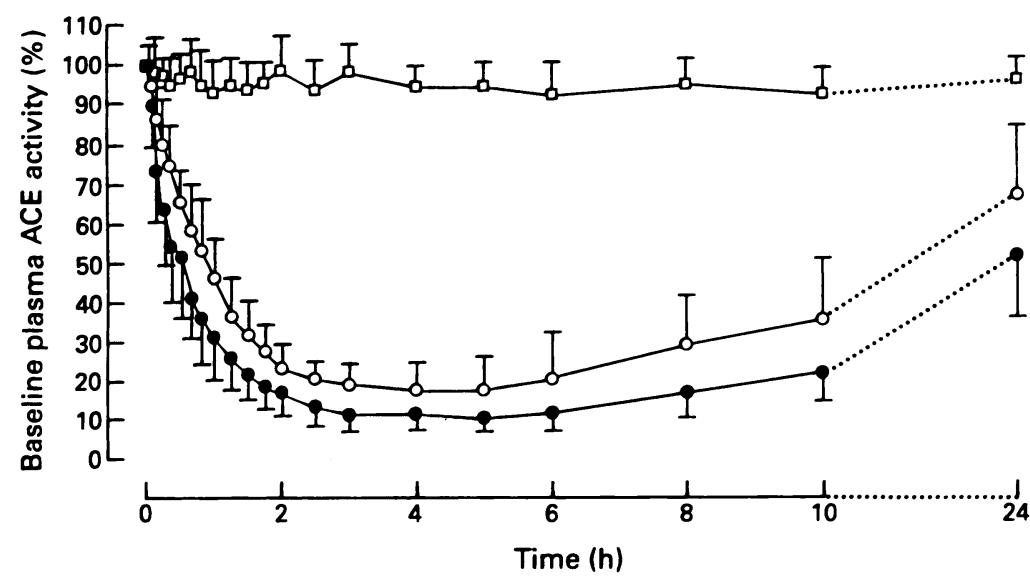

Figure 3 Plasma angiotensin converting enzyme inhibiton (mean (SD), $n=12$ ) as a percentage of baseline activity after intravenous placebo ( $\square$ ), enalaprilat ( $\bigcirc)$, or perindoprilat (O). enalaprilat concentrations was $4 \cdot 8(1 \cdot 6) \mathrm{h}$ and for perindoprilat $5 \cdot 3(1 \cdot 1) \mathrm{h}$ and as expected the drug concentrations were in each case maximal at the end of the individual infusions. During infusion both treatments were associated with a sigmoid shaped drug concentration profile that has previously been reported. ${ }^{16}$

The profile of plasma ACE inhibition was similar for both active treatments, showing a rapid onset and sustained plateau (fig 3). The mean maximal inhibition of plasma ACE activity was higher $(p=0.004)$ for the perindoprilat group $(91 \cdot 7)(3 \%)$ compared with the enalaprilat group $(86.5 \%(4 \%))$. Mean maximal ACE inhibition across the whole group was reached at $4.5(1.3) \mathrm{h}$ in the perindoprilat group and $5 \cdot 0(1 \cdot 2) \mathrm{h}$ in the enalaprilat group.

Plasma renin activity was significantly raised by both active treatments compared with placebo (fig 4) and remained high after discontinuation of infusion.

\section{Discussion}

The two diacid ACE inhibitors given intravenously in our study caused similar falls in blood pressure. Intravenous infusion, with the option of an early end of treatment, controlled the haemodynamic responses. We think that this is preferable to bolus, higher dose, strategies used in other studies with enalaprilat $^{17-19}$ or other ACE inhibitors. ${ }^{20-22}$ To optimise blood pressure response of the patients to dose titration may be worthwhile especially after myocardial infarction. ${ }^{11}$

The contrast between the similar blood pressure responses with perindoprilat and enalaprilat and those previously reported with a similar protocol in our earlier study is of interest. ${ }^{12}$ We previously reported a different pattern of blood pressure change after oral perindopril $(2 \mathrm{mg})$ compared with enalapril $(2.5 \mathrm{mg})$ orally, despite similar inhibition of plasma ACE: whereas enalapril produced a slow and sustained fall in blood pressure compared with placebo, perindopril had no discernible effect.

Our present study, which was concurrent and of identical design, led to comparable plasma ACE inhibition, and both intravenous drugs reduced blood pressure. The perindoprilat concentrations after intravenous administration were higher than those previously achieved after oral perindopril. ${ }^{12}$ The prodrug ester (perindopril) that after oral dosing appears first in the systemic circulation before the generation of significant quantities of the active diacid metabolite (perindoprilat) may influence the blood pressure response. We postulate that this lipophilic ester, with its weak ACE inhibiting properties, may undergo rapid tissue distribution and interaction with the tissue based angiotensin generating system. ${ }^{23}$ From in vitro work it seems that perindopril, the parent compound, may reduce inhibition of ACE by perindoprilat, the metabolite. ${ }^{24}$ Any interaction between the parent compound and metabolite would be 


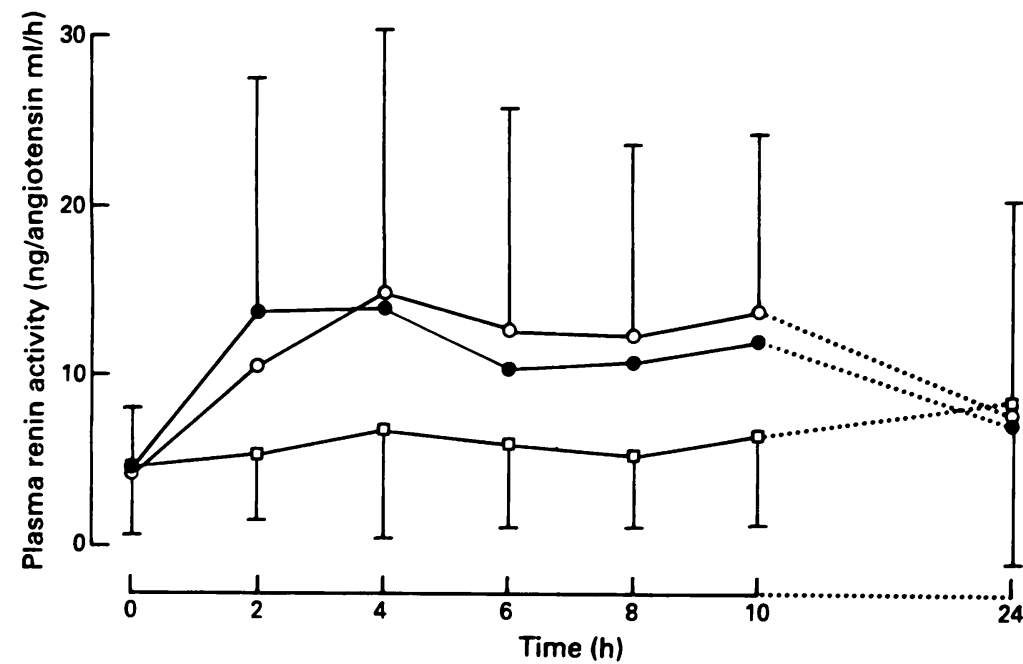

Figure 4 Plasma renin activity (mean (SD), $n=12$ ) after infusion of intravenous placebo ( $\square$ ), enalaprilat (O), or perindoprilat (O).

expected to be most prominent after the initial dose, it would be expected to be dose and concentration dependent, and it could produce effects that would vary among tissues.

We propose that prolonged low dose intravenous ACE inhibitors may be useful when starting treatment in heart failure patients at risk of excessive falls in blood pressure. Falls in blood pressure can be controlled by stopping the infusion. A formal trial of this approach in a further high risk population is justified.

This study was supported by the British Heart Foundation. We are grateful for the support of Drs F G Dunn, W S Hillis (Stobhill Hospital) and J A Kennedy (Western Infirmary) for allowing us to study their patients, to Servier Laboratories (Slough UK) and MSD Laboratories (Hoddesdon UK) fo supplies of perindoprilat and enalaprilat, to $\mathrm{Mr} G \mathrm{M}$ Thomson and Ms L M Gilbert (Department of Pharmacy, Stobhill Hospital) for randomisation and preparation of infusions, to Mr J McCulloch and Mr D M Hughes for technical support, and to Mrs J Hamilton for typing the manuscript.

1 Packer $M$. Therapeutic options in the management of chronic heart failure, is there a drug of first choice? Circulation 1989;79:198-204.

2 The CONSENSUS trial study group. Effects of enalapril on mortality in severe congestive heart failure: results of the co-operative North Scandinavian Enalapril Survival Study (CONSENSUS). $N$ Engl $f$ Med 1987; 316: 1429-35.

3 SOLVD Investigators. Effect of enalapril on survival in patients with reduced left ventricular ejection fractions and congestive heart failure. $N$ Engl f Med 1991; 325:293-302.
4 Packer M, Gottlieb SS, Blum MA. Immediate and long term pathophysiologic mechanisms underlying the genesis of sudden cardiac death in patients with congestive heart failure. $A m \mathcal{F} \mathrm{Med}$ 1987;82(suppl 3A):4-10.

5 Johnston CI. Biochemistry and pharmacology of the renin angiotensin system. Drugs 1990;39(suppl 1):21-31.

6 Urata H, Healy B, Stewart RW, Bumpus FM, Husain A. Angiotensin II forming pathways in normal and failing human hearts. Circ Res 1990;66:883-90.

7 Linz W, Scholkens BA, Ganten D. Converting enzyme inhibition specifically prevents the development and induces regression of cardiac hypertrophy in rats. Clin Exp Hypertens $[A]$ 1989;11:1325-50.

8 MacFadyen RJ, Lees KR, Reid JL. Tissue and plasma angiotensin converting enzyme and the response to ACE inhibitor drugs. Br $\mathcal{f}$ Clin Pharmacol 1991;31: $1-14$.

9 Lamas GA, Pfeffer MA. Left ventricular remodelling after acute myocardial infarction: clinical course and beneficial effects of angiotensin-converting enzyme inhibition. Am Heart f 1991;121:1194-202.

10 Sharp N, Smith H, Murphy J, Greaves S, Hart H, Gamble G. Early prevention of left ventricular dysfunction after infarction with angiotensin converting enzyme inhibition. Lancet 1991;337:872-6.

11 Nabel EG, Topol EJ, Galeana A, et al. A randomised placebo controlled trial of combined early intravenous captopril and recombinant tissue type plasminogen activator therapy in acute myocardial infarction. $\mathcal{f} \mathrm{Am}$ Coll vator therapy in acute myoc
Cardiol 1991;17:467-73.

12 MacFadyen RJ, Lees KR, Reid JL. Differences in first dose response to ACE inhibition in congestive cardiac failure-a placebo controlled study. $\mathrm{Br}$ Heart $\mathcal{f} 1991$; 66:206-11.

13 Cushman DW, Cheung HS. Spectrophotometric assay and properties of the angiotensin converting enzyme of rabbit lung. Biochem Pharmacol 1971;20:1637-48.

14 Chiknas SG. A liquid chromatography assisted assay for angiotensin converting enzyme (peptidyl dipeptidase) in serum Clin Chem 1979;25:1259-62.

15 Derkx FHM, Tan-Tjiong HL, Man in't Veld AJ, Schalekamp MAP, Schalekamp MADH. Activation of inactive plasma renin by plasma and tissue kallikreins. inactive plasma renin by

16 MacFadyen RJ, Lees KR, Reid JL. Studies with low dose intravenous diacid ACE inhibitor (perindoprilat) infusions in normotensive male volunteers. $\mathrm{Br} f \mathcal{C l i n}$ Pharmacol 1992;34:115-21.

17 Kubo SH, Cody RJ, Laragh JH, et al. Immediate converting enzyme inhibition with intravenous enalapril in chronic congestive heart failure. Am f Cardiol 1985;55 $122-6$.

18 De Marco T, Daly PA, Liu M, Kayser S, Parmley WW, Chatterjee K. Enalaprilat, a new parenteral angiotensin converting enzyme inhibitor: rapid changes in systemic and coronary haemodynamics and humoral profile in chronic heart failure. $\mathcal{F}$ Am Coll Cardiol 1987;9:1131-8.

19 Hornung RS, Hillis WS. The acute haemodynamic effects of intravenous enalaprilic acid (MK 422) in patients of intravenous enalaprilic acid (MK 4 2lin Pharmacol with left ventricul

20 Rademaker M, Shaw TRD, Williams BC, et al. Intravenous captopril in patients with severe cardiac failure. Br Heart $\mathcal{F}$ 1986;55:187-90

21 Dickstein K, Aarsland T, Tjelta K, Cirillo VJ, Gomez HJ A comparison of the hypotensive responses after oral and intravenous administration of enalapril and lisinopril in chronic heart failure. 7 Cardiovasc Pharmaco 1987;9:705-10.

22 Volpini M, Gargano M, Cuccia C, et al. Acute haemodynamic effects of intravenous captopril in patients with chronic congestive heart failure. Cardiologica 1989;34: 517-23.

23 Fabris B, Jackson B, Kohzuki M, Perich R, Johnston CI. with chronic heart failure. Clin Exp Pharmacol Physiol with chronic heart

24 Harrigan JR, Hughes DM, Meredith PA, Reid JL. Characterisation of the effects of prodrug concentration on the in vitro potency of the metabolites of five $\mathrm{ACE}$ inhibitors. Eur f Clin Pharmacol 1989;36 (suppl):A186. 